\title{
Negative Charge
}

National Cancer Institute

\section{Source}

National Cancer Institute. Negative Charge. NCI Thesaurus. Code C81173.

Having a surplus of electrons; having a lower electric potential. 